\title{
Distribution
}

\section{of acquired antibiotic resistance genes among Enterococcus spp. isolated from a hospital in Baotou, China}

\author{
Yingjie Tian, Hui Yu and Zhanli Wang *
}

\begin{abstract}
Objective: This study investigated the distribution of acquired antibiotic resistance genes in Enterococcus species isolated from clinical patients in Baotou, China.

Result: A total of 73 enterococca lisolates from clinical samples were collected from December 2016 to September 2017. Of the 73 enterococcal isolates, 36 (49.3\%), 35 (47.9\%), 1 (1.4\%), and 1 (1.4\%) were identified as E. faecium, E. faecalis, E. gallinarum, and E. raffinosus, respectively. The resistance rates of the enterococci to nitrofurantoin, tetracycline, gentamicin (high-level), ampicillin, ciprofloxacin and erythromycin were 24.7\%, 49.3\%, 50.7\%, 54.8\%, 74.0\% and 89.0\%, respectively. The most prevalent aminoglycoside resistance genes were aac(6')-le-aph(2')-la (64.9\%) and aph(3')IIla (64.9\%). The most common erythromycin ribosome methylation gene was erm(B) (67.7\%), followed by erm(A) (4.6\%) and erm(C) (1.5\%). The tetracycline resistance gene tetM was found to be present in $100.0 \%$ of the tetracycline-resistant strains of enterococci. Thus, E. faecium and E. faecalis were identified as the species of greatest clinical importance associated with hospital-acquired enterococcal infections in Baotou, China. The antimicrobial resistance genes aac(6')-le-aph(2')-la, aph(3')IIla, tetM, and erm(B) were significantly more prevalent among the enterococcal isolates. Therefore, action should be taken to monitor drug resistance and antimicrobial resistance genes to manage multidrug-resistant enterococcal infections.
\end{abstract}

Keywords: Enterococcus, Drug resistance, Antibiotic resistance gene, Infection

\section{Introduction}

Enterococci have long been considered symbiotic organisms of humans that have the potential to accidentally invade the host [1]. Recently, Enterococcus species have emerged as important pathogens causing hospitalacquired and community-acquired abdominal infections [2]. The common infection sites are the urinary tract, surgical sites, respiratory tract, gastrointestinal tract, skin and soft tissue. In addition, the incidence of infections caused by multi-drug-resistant isolates of enterococci

*Correspondence: wang.zhanli@hotmail.com

The Second Affiliated Hospital, Baotou Medical College, 30

Hude Mulin Street, Baotou 014030, China is increasing worldwide, which is a serious problem for clinical anti-infective therapy [3].

Many studies have reported that enterococci are resistant to a wide range of antimicrobial agents via intrinsic and acquired mechanisms [4]. The mechanism underlying the acquisition of antibiotic resistance genes has been recognized for several decades. High-level aminoglycoside resistance is primarily due to the acquisition of genes encoding aminoglycoside-modifying enzymes

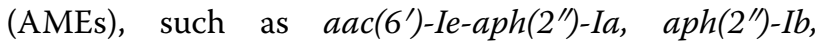
$\operatorname{aph}\left(2^{\prime \prime}\right)-I c$, aph(2')-Id, and aph(3')IIIa [5]. Erythromycin resistance among enterococci is associated with the presence of erythromycin resistance methylase $(\mathrm{erm})$ genes, such as $\operatorname{erm}(A), \operatorname{erm}(B)$, and $\operatorname{erm}(C)$. The predominant erm gene in erythromycin-resistant isolates of enterococci is the $\operatorname{erm}(B)$ gene, which encodes the ribosomal 
RNA methylase [6]. Moreover, there are currently over 40 different acquired tetracycline resistance genes recognized. The $t e t(M)$ gene is the tetracycline resistance gene with the broadest host range [7]. The protein encoded by the tet $M$ gene blocks the binding of tetracycline to the ribosome by combining with the $50 \mathrm{~S}$ ribosomal subunit, causing a conformational change in the ribosome that subsequently produces drug resistance.

The difficulty in treating enterococcal infections is associated with antimicrobial resistance. Therefore, the study of the distribution of resistance genes and resistance mechanisms of enterococci to guide clinical treatment is particularly important. The aim of the present study was to determine the antibiotic susceptibility of enterococci, examine the presence of genes encoding AMEs (including $a a c\left(6^{\prime}\right)-I e-a p h\left(2^{\prime \prime}\right)-I a$, $a p h\left(2^{\prime \prime}\right)-I b$, $\operatorname{aph}\left(2^{\prime \prime}\right)-I c$, aph $\left(2^{\prime \prime}\right)-I d$, and $\left.\operatorname{aph}\left(3^{\prime}\right)-I I I a\right)$ and the erm factors (including $\operatorname{erm}(A)$, $\operatorname{erm}(B)$, and $\operatorname{erm}(C)$ ), and identify the tet $(M)$ gene of enterococcal isolates from clinical patients in Baotou, China.

\section{Main text \\ Methods \\ Bacterial strains and identification}

A total of 73 clinical isolates of enterococci were collected from the Second Affiliated Hospital of Baotou Medical College in Baotou, China, between December 2016 and September 2017. Duplicate and contaminated isolates were excluded from the study. Institutional ethical clearance was obtained. Conventional biochemical tests and the Phoenix100 automatic system (BD, USA) were used to identify the isolates as enterococci. Identifications of E. faecalis, E. faecium and the other strains were further confirmed via PCR analysis as described previously [8].

\section{Susceptibility testing}

Antimicrobial susceptibility testing was performed by using the disc diffusion method according to the standards and interpretive criteria described by the Clinical and Laboratory Standards Institute (CLSI) [9]. The following drugs were tested: gentamicin $(120 \mu \mathrm{g})$, erythromycin $(15 \mu \mathrm{g})$, vancomycin $(30 \mu \mathrm{g})$, teicoplanin $(30 \mu \mathrm{g})$, ciprofloxacin $(5 \mu \mathrm{g})$, ampicillin $(10 \mu \mathrm{g})$, linezolid $(30 \mu \mathrm{g})$, tetracycline $(30 \mu \mathrm{g})$, and rifampin $(5 \mu \mathrm{g})$. E. faecalis ATCC29212 was used as a reference strain.

\section{Amplification of antimicrobial resistance genes}

Total DNA was extracted from enterococci according to the instruction manuals of commercial DNA extraction kits (Tiangen Biotech Co., Ltd., Beijing, China). The presence of the antimicrobial resistance genes was detected by PCR (see Additional file 1: Table S1) [10-13]. PCR amplification was performed using $5 \mu \mathrm{l}$ of template DNA,
$2 \mu \mathrm{l}$ of each primer ( $100 \mathrm{pmol})$, and $25 \mu \mathrm{l}$ of $2 \times$ Taq PCR MasterMix (Solarbio Science \& Technology Co., Ltd., Beijing, China) in a total reaction volume of $50 \mu \mathrm{l}$. The PCR conditions consisted of an initial denaturation step at $94{ }^{\circ} \mathrm{C}$ for $3 \mathrm{~min}$, followed by 35 cycles of denaturation at $94{ }^{\circ} \mathrm{C}$ for $30 \mathrm{~s}$, annealing for $30 \mathrm{~s}$, and elongation at $72{ }^{\circ} \mathrm{C}$ for $1 \mathrm{~min}$. A final extension step was carried out at $72{ }^{\circ} \mathrm{C}$ for $5 \mathrm{~min}$.

\section{Statistical analysis}

All statistical analyses were performed using Statistical Package for Social Sciences (SPSS) software (version $17.0)$. Probability values (p) of $<0.05$ were considered statistically significant.

\section{Results}

\section{Identification of Enterococcus species}

A total of 73 enterococcus isolates were obtained from different clinical samples as follows: urine $(n=36,49.3 \%)$, pus $(\mathrm{n}=11,15.1 \%)$, bile $(\mathrm{n}=10,13.7 \%)$, wounds $(\mathrm{n}=8$, $11.0 \%)$, hydrothorax $(n=3,4.1 \%)$, blood $(n=2,2.7 \%)$, and others $(\mathrm{n}=3,4.1 \%)$. Among the 73 strains of enterococci, E. faecium $(\mathrm{n}=36,49.3 \%)$ and E. faecalis $(\mathrm{n}=35$, $47.9 \%$ ) were identified as the dominant species presented in this study, along with E. gallinarum $(\mathrm{n}=1,1.4 \%)$ and E. raffinosus $(\mathrm{n}=1,1.4 \%)$.

\section{Antimicrobial susceptibility}

Among the 9 antibacterial agents tested, the frequencies of resistance of enterococci to nitrofurantoin, tetracycline, gentamicin (high-level), ampicillin, ciprofloxacin and erythromycin were $24.7 \%$, 49.3\%, 50.7\%, 54.8\%, 74.0\% and $89.0 \%$, respectively (see Additional file 2: Table S2). All strains were sensitive to teicoplanin, vancomycin and linezolid. There was a significant difference in the resistance to ampicillin between E. faecium and E. faecalis species $(\mathrm{p}<0.05)$. However, no significant differences in resistance rates to tetracycline $(\mathrm{p}=0.059)$, gentamicin $(\mathrm{p}=0.479)$, ciprofloxacin $(\mathrm{p}=0.173)$, and erythromycin $(\mathrm{p}=0.226)$ were observed.

\section{Distribution of aminoglycoside resistance genes}

The frequency of the studied AME genes among Enterococcus species is shown in Table 1 . Of the 17 E. faecium isolates with high-level gentamicin resistance (HLGR), $\operatorname{aac}\left(6^{\prime}\right)-I e-a p h\left(2^{\prime \prime}\right)-I a$ was the most prevalent $(\mathrm{n}=12$, $70.6 \%)$, followed by aph(3')-IIIa $(\mathrm{n}=9,52.9 \%)$ and $\operatorname{aph}\left(2^{\prime \prime}\right)-I d(\mathrm{n}=4,23.5 \%)$. However, the frequencies of resistance genes among the 20 HLGR E. faecalis isolates were as follows: $\operatorname{aph}\left(3^{\prime}\right)-I I I a(\mathrm{n}=15,75.0 \%)$, aac $\left(6^{\prime}\right)-I e$ $\operatorname{aph}\left(2^{\prime \prime}\right)-I a(\mathrm{n}=12,60.0 \%)$ and $\operatorname{aph}\left(2^{\prime \prime}\right)-I d(\mathrm{n}=3,15.0 \%)$. Neither the $a p h\left(2^{\prime \prime}\right)-I b$ nor the $a p h\left(2^{\prime \prime}\right)-I c$ gene was detected among all of the HLGR isolates. No significant 
Table 1 Distribution of aminoglycoside modifying enzyme genes in enterococci

\begin{tabular}{|c|c|c|c|}
\hline \multirow[t]{2}{*}{ AME gene } & \multicolumn{2}{|c|}{$\begin{array}{l}\text { Distribution of HLGR } \\
\text { in enterococci }(n=37)\end{array}$} & \multirow{2}{*}{$\begin{array}{l}\text { Total } \\
\text { no. (\%) } \\
\text { of isolates }\end{array}$} \\
\hline & $\begin{array}{l}\text { E. faecalis } \\
(n=20)\end{array}$ & $\begin{array}{l}\text { E. faecium } \\
(n=17)\end{array}$ & \\
\hline $\operatorname{aac}\left(6^{\prime}\right)-l e-a p h\left(2^{\prime \prime}\right)-1 a$ & 12 & 12 & $24(64.9 \%)$ \\
\hline$a p h\left(2^{\prime \prime}\right)-1 b$ & - & - & - \\
\hline $\operatorname{aph}\left(2^{\prime \prime}\right)-1 c$ & - & - & - \\
\hline $\operatorname{aph}\left(2^{\prime \prime}\right)-1 d$ & 3 & 4 & $7(18.9 \%)$ \\
\hline$a p h\left(3^{\prime}\right) \| l a$ & 15 & 9 & $24(64.9 \%)$ \\
\hline $\begin{array}{l}\operatorname{aac}\left(6^{\prime}\right)-1 e-a p h\left(2^{\prime \prime}\right)-1 a+a p h\left(2^{\prime \prime}\right)- \\
\text { Id }\end{array}$ & 2 & 3 & $5(13.5 \%)$ \\
\hline $\begin{array}{l}\operatorname{aac}\left(6^{\prime}\right)-1 e-a p h\left(2^{\prime \prime}\right)-1 a+a p h\left(3^{\prime}\right) \\
\quad I I a\end{array}$ & 8 & 6 & $14(37.8 \%)$ \\
\hline$a p h\left(2^{\prime \prime}\right)-1 d+a p h\left(3^{\prime}\right) \| l a$ & 3 & 4 & $7(18.9 \%)$ \\
\hline $\begin{array}{l}a a c\left(6^{\prime}\right)-l e-a p h\left(2^{\prime \prime}\right)-1 a+a p h\left(2^{\prime \prime}\right)- \\
I d+a p h\left(3^{\prime}\right) \| l a\end{array}$ & 2 & 3 & $5(13.5 \%)$ \\
\hline
\end{tabular}

differences in the distribution of the evaluated AME genes were observed between E. faecalis and E. faecium (see Additional file 3: Table S3). Additionally, 31 HLGR enterococcal isolates $(83.8 \%)$ carried two or more different AME genes (see Table 1). Moreover, 3 HLGR isolates $(8.1 \%)$ and all of the gentamicin-susceptible isolates were negative for the examined AME genes.

\section{Distribution of erythromycin resistance genes}

Table 2 shows the presence of erythromycin resistance genes among erythromycin- resistant enterococcus isolates. The frequencies of the erythromycin resistance genes were as follows: $\operatorname{erm}(B)(\mathrm{n}=44,67.7 \%) \operatorname{erm}(A)$ $(\mathrm{n}=3,4.6 \%)$, and $\operatorname{erm}(C)(\mathrm{n}=1,1.5 \%)$. Of the 31 erythromycin-resistant isolates of $E$. faecium, the majority of the isolates were positive for $\operatorname{erm}(B)(\mathrm{n}=17,54.8 \%)$, followed by $\operatorname{erm}(A)(\mathrm{n}=3,9.7 \%)$ and $\operatorname{erm}(C)(\mathrm{n}=1,3.2 \%)$. Similarly, of the 33 erythromycin-resistant isolates of $E$. faecalis, 26 isolates (78.8\%) carried $\operatorname{erm}(B)$, while neither $\operatorname{erm}(A)$ nor $\operatorname{erm}(C)$ was detected. No significant differences in the distribution of the erythromycin resistance

Table 2 Distribution ofErythromycin resistance genes in enterococci

\begin{tabular}{lllll}
\hline Gene & \multicolumn{2}{l}{$\begin{array}{l}\text { Distribution of Erythromycin } \\
\text { resistance in enterococci }(\mathbf{n = 6 5 )}\end{array}$} & \multirow{2}{*}{$\begin{array}{l}\text { Total no.(\%) } \\
\text { of isolates }\end{array}$} \\
\cline { 2 - 4 } & $\begin{array}{l}\text { E. faecalis } \\
(\mathbf{n}=\mathbf{3 3 )}\end{array}$ & $\begin{array}{l}\text { E. faecium } \\
(\mathbf{n}=\mathbf{3 1})\end{array}$ & $\begin{array}{l}\text { E. raffinosus } \\
(\mathbf{n}=\mathbf{1})\end{array}$ \\
\hline $\operatorname{erm}(A)$ & - & 3 & - & $3(4.6 \%)$ \\
$\operatorname{erm}(B)$ & 26 & 17 & 1 & $44(67.7 \%)$ \\
$\operatorname{erm}(C)$ & - & 1 & - & $1(1.5 \%)$ \\
$\operatorname{erm}(A)+\operatorname{erm}(B)$ & - & 1 & - & $1(1.5 \%)$ \\
\hline
\end{tabular}

genes were identified between E. faecalis and E. faecium (see Additional file 3: Table S3). In 1 isolate (100\%) of erythromycin-resistant $E$. raffinosus, the $\operatorname{erm}(B)$ gene was detected. Furthermore, only 1 isolate $(1.5 \%)$ of the erythromycin-resistant enterococci contained both $\operatorname{erm}(B)$ and $\operatorname{erm}(A)$. However, 17 isolates (26.2\%) did not carry any of the examined erm genes. Our results revealed that the isolates of erythromycin-susceptible enterococci were negative for the erm genes examined in this study.

\section{Distribution of the tetracycline resistance gene}

Table 3 shows the frequency of the tet $M$ gene among the 36 tetracycline- resistant enterococcal isolates, including 14 isolates of E. faecium and 22 isolates of E. faecalis. All of these tetracycline-resistant strains of enterococci were found to be positive for the tet $M$ gene. The tet $M$ gene was absent in all the tetracycline-susceptible isolates.

\section{Discussion}

It has been shown that enterococci are opportunistic nosocomial pathogens capable of causing various infectious diseases. Many Enterococcus species have been reported, and E. faecium and E. faecalis are the most common human infectious strains of Enterococcus [14, 15]. This finding is similar to that observed in the present report.

It appears that the increased prevalence of multi-drugresistant Enterococcus species has become a major public health problem. In the current study, a high percentage of enterococci exhibited resistance to erythromycin (89.0\%), ciprofloxacin $(74.0 \%)$, ampicillin $(54.8 \%)$, gentamicin (high-level) (50.7\%), tetracycline (49.3\%) and nitrofurantoin $(24.7 \%)$. However, the isolates were highly sensitive to the following antibiotics: teicoplanin (0 resistant strains), linezolid (0 resistant strains), and vancomycin (0 resistant strains), similar to other reports [16]. In this study, the rate of ampicillin resistance in E. faecium species showed a significant difference when compared to that of E. faecalis, which is in agreement with previous studies [17].

The presence of AME genes, such as $a a c\left(6^{\prime}\right)-I e-a p h\left(2^{\prime \prime}\right)$ -

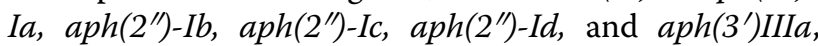
that are responsible for high-level gentamicin resistance,

\begin{tabular}{|c|c|c|c|}
\hline \multirow[t]{2}{*}{ gene } & \multicolumn{2}{|c|}{$\begin{array}{l}\text { Distribution of tetracycline resistance } \\
\text { in enterococci }(n=36)\end{array}$} & \multirow[t]{2}{*}{$\begin{array}{l}\text { Total no.(\%) } \\
\text { of isolates }\end{array}$} \\
\hline & E. faecalis $(n=22)$ & E. faecium $(n=14)$ & \\
\hline tetM & 22 & 14 & $36(100 \%)$ \\
\hline
\end{tabular}


have been extensively reported [18]. Our previous studies found that $a a c\left(6^{\prime}\right)-I e-a p h\left(2^{\prime \prime}\right)-I a$ was the most common AME gene [15]. In the current study, a high prevalence of the $a p h\left(3^{\prime}\right)-I I I a$ gene was also found. We further showed that $37.8 \%$ of the HLGR enterococcal isolates carried both $a a c\left(6^{\prime}\right)-I e-a p h\left(2^{\prime \prime}\right)-I a$ and $a p h\left(3^{\prime}\right)$-IIIa, which was higher than our previous results [15]. Moreover, $8.1 \%$ of the HLGR enterococcal isolates did not carry any of the examined AME genes. This was lower than that previously reported by Li et al. [19].

The presence of a wide range of erythromycin resistance genes in Enterococcus species has been reported elsewhere [20]. In the present study, the most abundant erm gene was $\operatorname{erm}(B)$, followed by $\operatorname{erm}(A)$ and $\operatorname{erm}(C)$. A Previous study by Quiñones Pérez et al. found that $70.9 \%$ of erythromycin-resistant enterococcal isolates examined in their study carried $\operatorname{erm}(B)$ [21]. This value is close to that obtained in our present study (67.7\%). In addition, the $\operatorname{erm}(A)$ and $\operatorname{erm}(C)$ genes were only detected in erythromycin-resistant isolates of E. faecium, which was a rarer occurrence than that previously reported [22]. Moreover, 17 isolates $(26.2 \%)$ of the erythromycin- resistantent erococci were negative for the erm genes examined in this study. It is possible that other genes could be associated with erythromycin- resistant enterococcal isolates, such as $\operatorname{erm}(D), \operatorname{erm}(E), \operatorname{erm}(F), \operatorname{erm}(G)$, $\operatorname{erm}(Q)$, and the macrolide efflux pump ( $m s r A)$.

Acquired resistance to tetracyclines in enterococci is often by mobile genetic elements [23]. The detection of the tetM gene by PCR has frequently been used to monitor tetracycline resistance in microbial populations [24]. The results of this study showed that $100 \%$ of the tetracycline-resistant Enterococcus isolates carried the tet $M$ gene, which was higher than previously reported prevalences [25].

\section{Conclusions}

Enterococcus species have become a significant cause of hospital-acquired infections. The present study showed that enterococci recovered from clinical samples in Baotou, China, contained a variety of antimicrobial resistance genes. These results will be helpful in clarifying the transmission mechanisms of antibiotic-resistant Enterococcus species.

\section{Limitations}

This study tried to address the distribution of acquired antibiotic resistance genes among Enterococcus species isolated from a hospital in Baotou, China. However, the study was not without limitations. This was a small study that could not include additional samples of Enterococcus species taken from this region. In addition, the study utilized PCR-based methods to detect some common acquired antibiotic resistance genes, and tests for several additional antibiotic resistance genes will be needed.

\section{Additional files}

Additional file 1: Table S1. PCR primers used in the amplification of resistance genes.

Additional file 2: Table S2. The resistance rate of the clinical isolates of enterococci species to various antimicrobial agents.

Additional file 3: Table S3. Differences in the prevalence of resistance genes between E. faecalis and E. faecium were compared using the Chi square test, with a $p$ value $<0.05$ indicating statistical significance.

\section{Abbreviations}

K-B assay: Kirby-Bauer assay; AME: aminoglycoside-modifying enzyme; CLSI: Clinical and Laboratory Standards Institute; HLGR: high-level gentamicin resistance.

\section{Authors' contributions}

YT conducted the study, collected the data, performed the analysis of the data, and prepared the manuscript; HY conducted the study, collected the data, and performed the analysis of the data; ZW designed and supported the study, and edited the manuscript. All authors read and approved the final manuscript.

\section{Acknowledgements}

We would like to thank the staff at the Clinical Microbiology Laboratory, The Second Affiliated Hospital, Baotou Medical College for their support.

\section{Competing interests}

The authors declare that they have no competing interests.

\section{Availability of data and materials}

The data analyzed in the present study may be obtained from the corresponding author upon reasonable request.

\section{Consent for publication}

Not applicable.

\section{Ethics approval and consent to participate}

Ethical approval was obtained from the Second Affiliated Hospital, Baotou Medical College Research and Ethical Review Committee. Informed written consent was obtained from each participant in the study. Any data generated from the specimens protected the patent privacy, confidentiality and anonymity.

\section{Funding}

This study was supported by research grants from the National Natural Science Fund $(81660048,81460049$, and 81760056$)$. The funder had no role in study design, data collection, analysis and interpretation, or preparation of the manuscript.

\section{Publisher's Note}

Springer Nature remains neutral with regard to jurisdictional claims in published maps and institutional affiliations.

Received: 7 December 2018 Accepted: 9 January 2019

Published online: 15 January 2019

\section{References}

1. Kuang YS, Li SH, Guo Y, Lu JH, He JR, Luo BJ, Jiang FJ, Shen H, Papasian CJ, Pang H, Xia HM, Deng HW, Qiu X. Composition of gut microbiota in infants in China and global comparison. Sci Rep. 2016;6:36666.

2. Toru M, Beyene G, Kassa T, Gizachew Z, Howe R, Yeshitila B. Prevalence and phenotypic characterization of Enterococcus species isolated from clinical samples of pediatric patients in Jimma University Specialized Hospital, south west Ethiopia. BMC Res Notes. 2018;11(1):281.

3. Ike Y. Pathogenicity of Enterococci. Nihon Saikingaku Zasshi. 2017;72(2):189-211. 
4. Gholizadeh Y, Courvalin P. Acquired and intrinsic glycopeptides resistance in Enterococci. Int J Antimicrob Agents. 2000;16(Suppl 1):S11-7.

5. Feizabadi MM, Maleknejad P, Asgharzadeh A, Asadi S, Shokrzadeh L, Sayadi S. Prevalence of aminoglycoside-modifying enzymes genes among isolates of Enterococcus faecalis and Enterococcus faecium in Iran. Microb Drug Resist. 2006;12(4):265-8.

6. Celik S, Cakirlar FK, Torun MM. Presence of vancomycin, aminoglycosides, and erythromycin resistance genes in enterococci isolated from clinical samples in Turkey. Clin Lab. 2014;60(11):1801-6.

7. Roberts MC. Resistance to tetracycline, macrolide-lincosamide-streptogramin, trimethoprim, and sulfonamide drug classes. Mol Biotechnol. 2002;20(3):261-83.

8. Macovei L, Zurek L. Ecology of antibiotic resistance genes: characterization of enterococci from house flies collected in food settings. Appl Environ Microbiol. 2006;72(6):4028-35.

9. Clinical and Laboratory Standards Institute, Wayne, PA. Performance standards for antimicrobial susceptibility testing: Twentieth informational supplement. 2014. p. M100-S23.

10. Emaneini M, Bigverdi R, Kalantar D, Soroush S, Jabalameli F, Noorazar Khoshgnab B, Asadollahi P, Taherikalani M. Distribution of genes encoding tetracycline resistance and aminoglycoside modifying enzymes in Staphylococcus aureus strains isolated from a burn center. Ann Burns Fire Disasters. 2013;26(2):76-80.

11. Sedaghat H, Esfahani BN, Mobasherizadeh S, Jazi AS, Halaji M, Sadeghi P, Emaneini M, Havaei SA. Phenotypic and genotypic characterization of macrolide resistance among Staphylococcus aureus isolates in Isfahan, Iran. Iran J Microbiol. 2017:9(5):264-70.

12. Gad GF, Abdel-Hamid AM, Farag ZS. Antibiotic resistance in lactic acid bacteria isolated from some pharmaceutical and dairy products. Braz J Microbiol. 2014;45(1):25-33.

13. Jia W, Li G, Wang W. Prevalence and antimicrobial resistance of Enterococcus species: a hospital-based study in China. Int J Environ Res Public Health. 2014;11(3):3424-42.

14. Tsiodras S, Gold HS, Coakley EP, Wennersten C, Moellering RC Jr, Eliopoulos GM. Diversity of domain $\mathrm{V}$ of $23 \mathrm{~S}$ rRNA gene sequence in different Enterococcus species. J Clin Microbiol. 2000;38(11):3991-3.

15. Niu H, Yu H, Hu T, Tian G, Zhang L, Guo X, Hu H, Wang Z. The prevalence of aminoglycoside-modifying enzyme and virulence genes among enterococci with high-level aminoglycoside resistance in Inner Mongolia, China. Braz J Microbiol. 2016;47(3):691-6.
16. Ferede ZT, Tullu KD, Derese SG, Yeshanew AG. Prevalence and antimicrobial susceptibility pattern of Enterococcus species isolated from different clinical samples at Black Lion Specialized Teaching Hospital, Addis Ababa, Ethiopia. BMC Res Notes. 2018;11(1):793.

17. Asadollahi P, Razavi S, Asadollahi K, Pourshafie MR, Talebi M. Rise of antibiotic resistance in clinical enterococcal isolates during 2001-2016 in Iran: a review. New Microbes New Infect. 2018;26:92-9.

18. Feizabadi MM, Maleknejad P, Asgharzadeh A, Asadi S, Shokrzadeh L, Sayadi S. Prevalence of aminoglycoside-modifying enzymes genes among isolates of Enterococcus faecalis and Enterococcus faecium in Iran. Microb Drug Resist. 2006;12(4):265-8.

19. Li W, Li J, Wei Q, Hu Q, Lin X, Chen M, Ye R, Lv H. Characterization of aminoglycoside resistance and virulence genes among Enterococcus spp. isolated from a hospital in China. Int J Environ Res Public Health. 2015;12(3):3014-25.

20. Belén Flórez A, Alegría Á, Rossi F, Delgado S, Felis GE, Torriani S, Mayo B. Molecular identification and quantification of tetracycline and erythromycin resistance genes in Spanish and Italian retail cheeses. Biomed Res Int. 2014:2014:746859.

21. Quiñones DP, Abreu MC, Marrero D, Alvarez AB, Ortiz C, Salome F, Llop A, Campo R. Antimicrobial susceptibility and genetic bases for resistance of infection-causing Enterococcus strains in Cuba. Rev Panam Salud Publica. 2011;30(6):549-54.

22. Emaneini M, Khoramian B, Jabalameli F, Beigverdi R, Asadollahi K, Taherikalani M, Lari AR. Prevalence of high-level gentamicin-resistant Enterococcus faecalis and Enterococcus faecium in an Iranian hospital. J Prev Med Hyg. 2016;57(4):E197-200.

23. Hegstad K, Mikalsen T, Coque TM, Werner G, Sundsfjord A. Mobile genetic elements and their contribution to the emergence of antimicrobial resistant Enterococcus faecalis and Enterococcus faecium. Clin Microbiol Infect. 2010;16(6):541-54.

24. Aminov RI, Garrigues-Jeanjean N, Mackie RI. Molecular ecology of tetracycline resistance: development and validation of primers for detection of tetracycline resistance genes encoding ribosomal protection proteins. Appl Environ Microbiol. 2001;67(1):22-32.

25. Nishimoto Y, Kobayashi N, Alam MM, Ishino M, Uehara N, Watanabe N. Analysis of the prevalence of tetracycline resistance genes in clinical isolates of Enterococcus faecalis and Enterococcus faecium in a Japanese hospital. Microb Drug Resist. 2005;1 1(2):146-53.
Ready to submit your research? Choose BMC and benefit from:

- fast, convenient online submission

- thorough peer review by experienced researchers in your field

- rapid publication on acceptance

- support for research data, including large and complex data types

- gold Open Access which fosters wider collaboration and increased citations

- maximum visibility for your research: over $100 \mathrm{M}$ website views per year

At BMC, research is always in progress.

Learn more biomedcentral.com/submissions 